\title{
Harriet Holter: A Pioneer in Gender Studies and Sociology
}

Published in Acta Sociologica 2000; 43 (4): 413 - 421

Karin Widerberg, University of Oslo

karin.widerberg@sosiologi.uio.no

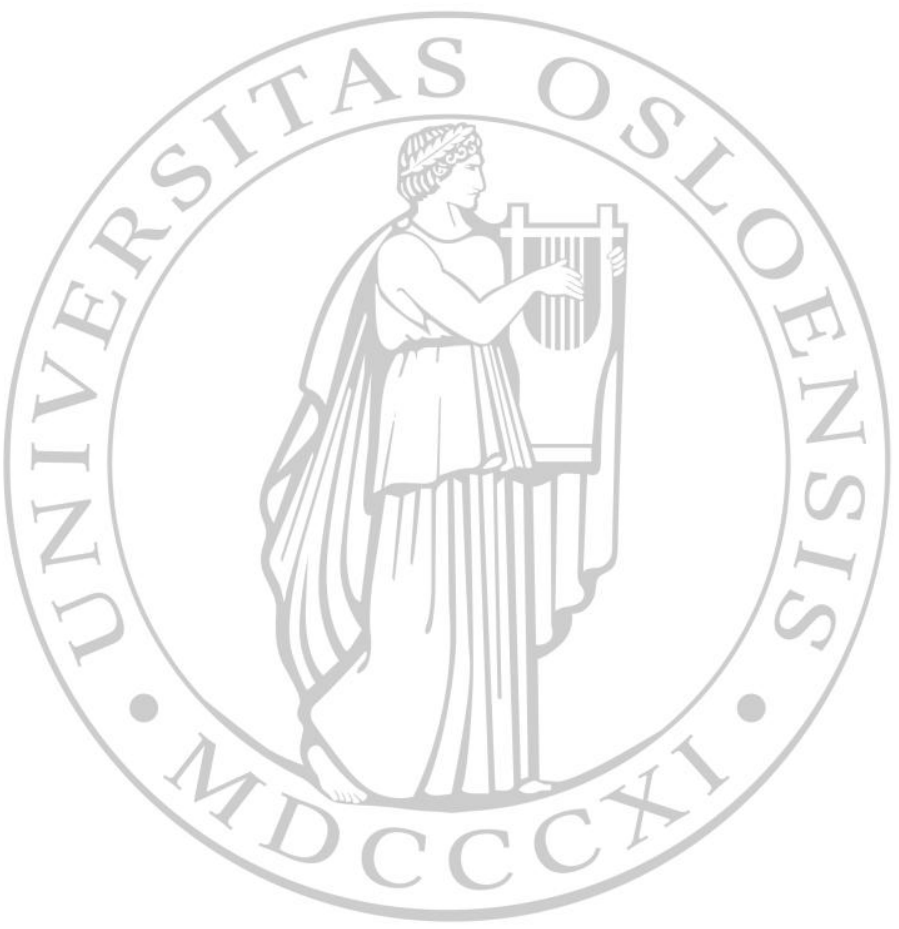

Department of Sociology and Human Geography University of Oslo

P.O.Box 1096 Blindern

N-0317 OSLO Norway

Telephone: $\quad+4722855257$

Fax:

$+4722855253$

Internet: http://www.iss.uio.no 


\title{
Harriet Holter - A Pioneer in Gender Studies and Sociology
}

\begin{abstract}
"In the sense that it is used in this monograph, sex differentiation has two facets, one normative and the other behavioral and attitudinal. The former refers to the norms, ideologies, values and beliefs that people apply to the two sexes. The latter refers to the actual similarities and differences in men and women...The distinction between the two aspects of differentiation makes it feasible to consider the relationships between them, which have obvious significance for the stability of the system, and for the genesis of the inner conflicts of individuals...Sex differentiation is one of society's distributive systems...The concept of sex differentiation is in the present work often distinguished from sex stratification; that is, from the ordering of the two genders in terms of power and social prestige" ( Holter 1970, p 17-18)
\end{abstract}

These lines from Harriet Holter's dissertation and book "Sex Roles and Social Structure" (Holter1970), express approaches to understandings of gender - as well as society - which are still valid today. Almost twenty years later, a definition of the gender system/order as based on two principles, segregation and hierarchy (Hirdman 1988), won general acceptance within Scandinavian women's research. Few of us knew or remembered, then, this heritage from Harriet Holter.

Harriet Holter was born in 1922 and died in 1997. She took her Ph. D in 1970 and was appointed Professor of Social Psychology at the University of Oslo in 1973. After her retirement in 1992 she was appointed Professor Emeritus at the Center for Women's Research, University of Oslo. She was awarded several prizes for her outstanding sociological contributions. She was also actively involved in research politics and was a member of several boards and committees at the Norwegian Research Council.

Harriet Holter was a pioneer, ahead of her time in more than one sense of the word. Few women of her generation took an academic degree, and fewer still majored in economics. Not satisfied with the approaches within economics, she ventured into other disciplines and in 1972 accepted a position as a professor in socialpsychology. She had a distinct voice, employing insights and modes of thinking from different disciplines. It was a voice of her own where structural approaches intermingle with inter-personal perspectives and personal reflections. She was a pioneer not only in academia but also in her private life. As a single 
mother in the early fifties and later as the love partner of a much younger man, she made some prodigious gender experiences. Her "gender project" in academia was evidently also her personal project. In many ways she made the motto"The Personal is Political" relevant long before it became a feminist slogan. This position as a pioneer, and as "outsider within", presumably affected her ways of thinking and her choice of paths to knowledge.

"Sex Roles and Social Structure" (Holter 1970), was the first major book on gender in Scandinvaia based on a social science perspective. It is a "Beauvoirian" effort to explain and make visible the making of gender, the first and the second sex. But here from a social science perspective, where the social processes and the differentiation of the two sexes into gender are focused and investigated on all levels. And where work - in all aspects of the word - is at the core.

With the concept of sex differentiation in norms and behavior, Harriet Holter sets out to illuminate and discuss the gender changes in and of modernity. The investigated arenas are work-life, politics and education. Quantitative empirical research, both Scandinavian and international, is here employed to challenge prevalent theoretical statements. She is, however, not out to present a smooth, one-dimensional and frictionless picture - in spite of the fact that she is clearly influenced by the structural functionalism dominant at the time. Quite the opposite. It is the complexities and the discrepancies that seem to fascinate her, and it is here that her reflections are still enormously interesting and relevant. When discussing discrepancies between ideologies and values, on the one hand, and informal norms and behavior, on the other, she states that:

"Another mechanism by which discrepancies are sometimes maintained is the assignment to separate agents of the responsibilities for implementing official values and informal norms. Politicians are among the primary guardians of the official value system, which is felt to belong in the public sphere. The family is held responsible for the informal, traditional norms, which are felt to belong in the private sphere. Official values and informal standards can remain inconsistent when there is little contact between the agents responsible for each" (Holter 1970, p. 170)

Today this discrepancy is investigated as "equality at a distance" and "equality nearby" (my translation of "jämställdhet långt borta" och "jämställdhet nära", from 
Magnusson 1998). And it is here to the level of "equality nearby" that Harriet Holter takes us, after having dealt with the previously mentioned arenas and presenting a discussion of discrepancies. Here we are introduced to a more psychological understanding of the gender roles, that is, a perspective that starts with the individual and moves to the social structure - rather than the other way around, which is the perspective that dominates the previous parts of the book. The word more is stressed here to signal that Harriet Holter is never solely psychological or sociological. Her insistence on being both at the same time and often in the very same sentence is typical for Harriet Holter. In this book concerning the social construction of gender, she obviously wants to illuminate the part played by "The Psychology of Maintaining Sex Differentiation" (the title of the chapter). Here perspectives are presented that we associate with those Chodorow later was famous for (Chodorow 1978). But she also presents an understanding of the socialization of gender roles which is still the prevalent one within sociology. The conccections she made here between sex roles and social structure, were unfortunately - not recycled in "Male-stream" sociology. Are they still too radical ?

"Role allocation by sex provides a simple, clear basis for distributing tasks which might otherwise be difficult to allocate...More significant for maintenance, sex differentiation in modern industrialized societies is an integral part of the total social organization in addition to being a cultural institution. As a system of norms it pervades all social functions so that changes in the bases of sex differentiation require parallel modifications in many other social institutions. The changes required in the structure of occupational life, for example, would be considerable should the responsibility for child-care and domestic work be reallocated and divided evenly between the sexes. The practical complications entailed in the use of principles other than sex for allocating child care and domestic work thus contribute to maintaining the current standards for assigning responsibilities to the two sexes. Since gender differentiation provides principles for the division of labor in most segments of society, the initiation of novel principles of allocation, even if they were restricted to the family, would of necessity, also require fundamental alterations of the rules for distributing tasks in occupational and political life" ( Holter 1970, p. 213-214)

The implications of sex differentiation are discussed in the final chapter of the book. Here, the relation between differentiation and stratification, of gender and class, is discussed for each sex and also between the sexes. Once again, the interpersonal relationships, the "Patterns of Cross-Sex and Same-Sex 
Relationships" are included in the overall picture. The individual man and woman and their daily gender struggles and negotiations, are given the final word. The hope for change, in society and gender relations, lies here, in our gender frustrations and solidarity.

"Sex Roles and Social Structure" is still - after thirty years - an impressive and important book. Although, the quantitative material and its approaches (investigations of attitudes) is today outdated as the main approach, many of the theoretical tools, concepts, reasoning and thoughts, still seem highly useful and relevant. Encouragingly or disencouragingly - depending on one's point of view we can find the seeds of some of the major issues in women's research of today, in her book. The opening citation, for example, includes, not only the concepts of differentiation and stratification (segregation and hierarchy) which are presented above, but also the concepts of gender and sex. Although Harriet Holter does not define gender - in fact, the concept does not become a topic for discussion and definition within women's research until more than ten years later - she uses this term to signal and define a social sex. I do not know of any others who used this concept at a time when it was considered to be only a grammatical term.

In accordance with this Harriet Holter was also original in stating that both genders - not just women - should be studied and that they should be understood as being related and relational.

"The main investigations of "women's roles" need to be supplemented by studies of "men's roles". Or rather, the roles of both sexes should be considered... The relative neglect of men's roles by social scientists is probably, in part, a reflection of the fact that it is women, not men, who complain most about the bases of role differentiation. It is also probable that social scientists make the common assumption that men constitute the norm with which members of the deviant sex, women should be compared. As expressed by Lysgaard (1963), "The man comes forward as a representative of the universal, he may be defined without reference to a complementary female role...he is less sex determined". Indeed, studies of women's roles are replete with implicit, usually untested, assumptions about men's attitudes and behaviors. Although the present monograph suffers at some points from the same implicit reasoning, an attempt is made to view men's and women's roles as part of an integrated system" ( Holter 1970, p. 16-17) 
Gender and class - a much debated issue within women's research during the mid seventies and the eighties - are also reflected upon here. The Swedish translation of the book - perhaps deliberately - makes possible a more radical understanding of this relationship. Here it is stated that "Sex differentiation is woven into both of these two social principles (horizontal and vertical - my addition) and contributes to their development" (my translation from the Swedish revised version, Holter 1973). The English version states "Sex differentiation thus contributes to the maintenance of horizontal structure of modern societies" ( Holter 1970, p. 224).

Other examples of original seeds influencing the thinking of women's research, can be found throughout the book, under each new section. This is especially true of the Swedish version. Here, in the chapter on sex differentiation in work-life, an additional section is devoted to a critique of the concept of work and work-life from a women's perspective (Holter 1973, p 122-123): by not including unpaid (domestic) labor, by making women's work invisible and accordingly making the conditions for men's paid labor invisible.

The same is true of her critique of psychoanalytical theory (not taking a power perspective into account)(Swedish version, Holter 1973). This section is also absent in the original English text. Reading the same book, in the English or the Scandinavian revised version, is a bit like reading two different books. The implicit absences in the English version, particularly in regard to power, are made more explicit and present in the later, Scandinavian version. The result of time passed and intellectual insights won, and/or, of a different - i.e. Scandinavian - social context?

These intellectual seeds for future ideas and concepts, were probably more or less unnoticed by most of us who read the book at the time. The book was so deep and we did not have sufficient knowledge to see what was at stake in her often intricate and subtle sentences. In this way she was a path-finder. In another way, the book was published too late. Although her research had been initiated in the sixties, before the women's movement and women's research got going, it was not published until the wind had changed. In the seventies' there was no time or patience for complex models and understandings, but one-dimensional - still though, important and fruitful - understandings took over the scene. In this light, sex-role theory was proclaimed a dead-end. Instead, structure and forces producing 
"sex-roles" (the concept was hardly used), or rather, gender were highlighted. Accordingly, Harriet Holter's book was less read than could have been expected of a book of this kind, or it was simply "misread". It was not until a decade or so later that the importance of the sex-role concept as a liberating concept for women implying that gender is not biological destiny but a social affair - was emphasized (see for example, Ve 1992). And only then was the difference between the Scandinavian sex-role theoreticians - of whom Harriet Holter was one of the most prominent - and their American predecessors (Talcott Parsons and others), profoundly articulated. Harriet Holter employed the concept of sex-roles in order to reveal how gender is used as a key to the distribution of gratifications and burdens in society, resulting in the discrimination of women. Parsons' understanding of the sex-roles as complementary and equal, was hereby overtaken. The aspect of power - and oppression - was accordingly the dividing line and distinction between the Scandinavian and the American sex-roles theoreticians .

Harriet Holter also moved with the wind, although a bit more reluctantly and always true to her intellectual perceptions. She added to rather than abandoned approaches and concepts. And what she had not included in her dissertation, she set out to investigate in her later work. Accordingly, two new areas were included in her "research profile" - the family and sexuality - while she remianed faithful to the power perspective (although somewhat implicit and vaguely formulated in her book, it is absolutely there). Even though she was never able to fully return to her dissertation and the concept of sex-roles, it is all there for us to contemplate. Rereading her dissertation today is an invitation to investigate and reflect upon what has actually taken place regarding gender and society in the course of the last 30 years, both in regard to actual gender differentiation and gender relations, but also in regard to ways of understanding gender. Like me, the reader will probably be struck not only by the dramatic changes that have obviously taken place but also by certain insights hitherto disregarded, but which definitely deserve to be reinvestigated (the statement quoted on page 2 , is one such example). Adding a generational perspective - which today, at least to me, seems strikingly lacking in her book - we could specify and empirically investigate several of her interesting statements. The book can serve not only to trace the heritage of sociology, but may also serve as an agenda for future research in gender and sociology. 


\section{Family as class}

Not having included the study of the family in her dissertation, and writing during the Marxist seventies, Harriet Holter embarked on a research project on "The Family in Class-Society" (the title of the book which emanated from this project, Holter et al. 1975). This time she did not work solely on her own, but rather formed a research group, which worked collectively. This was not rare in the seventies, but Harriet Holter continued to do research work like this, in and with groups (of different kinds) until the very end of her life. In fact, she developed ways of working collectively within women's research which deeply affected not only her own thinking, but also that of generations of women's researchers within all of Scandinavia. Her apptitude for "organizing for knowledge" gave her the informal title of "Mother of Scandinavian women's research" as well as more formal recognition, tasks, positions and funds from the Norwegian Research Council. This in turn benefitted younger generations of women's researchers.

The first time she took on this role as a head of research and supervisor for women's researchers of different generations (and in this instance, also a man) was in the project on the family in class-society. The project was initiated in 1969, before the leftist movement had made significant advances in research and academia. But it was implemented and carried out in dialogue with this movement. And this process is reflected in the book published in 1975.

One of the central goals of this project was the wish to highlight the internal relations of the family. Since this had been the object of traditional American family sociology, both empirically and theoretically, the project would provide a Scandinavian contribution and variant to the field. But in contrast to the American tradition, they set out to investigate and interpret internal family relations in light of surrounding social structures. More traditional sociological concepts of the family and various types of empirical data were interpreted from a Marxist perspective. This confrontation between two different approaches gave rise to critical discussions as well as a further development of traditional theories regarding family sociology. A dogmatic Marxist family analysis was thus also avoided. The resulting picture is rich and complicated, quite different from most of the books on the family published in the seventies. Let me give a few examples. 
By investigating both attitudes and behaviour - and problematizing the relationship between them - it is revealed that, in spite of the expressed traditional division of power within the working-class family, it is the mother who has the actual instrumental power. Within the middle-class family it is the other way around. Here, the mothers' attitudes do express more equality, but the father has the actual instrumental power. The research results also indicate that the working-class fathers are more family-oriented than are the middle-class fathers. By linking the concepts of "offensive - defensive" to those of "individuation - collectivism" it is further illustrated how families are offensive in class - specific ways. Class differences regarding socialization are explained in a similar way, that is, as expressions of actual class contradictions.

The aim to produce a more or less total understanding of the family in class-society, might seem somewhat portentious today. But in the seventies, partly as a reaction to bourgeois sociology which was claimed to make overall structural patterns invisible, one wouldn't settle for less. The empirical material of the project consisted of interviews with 30 families, in which different tests and "games" were included. Each family was visited 2-4 times and each visit lasted 3-4 hours. Of these families, three were picked out for case-studies. A separate study was also done on children, to investigate class differentiated socialization. Yet another study investigated the interaction of families within local settings and communities. Finally, in the second phase of the project, information and knowledge about family interactions was gathered by their working as co-therapists in family counseling.

The different studies and phases of the project demonstrate an effort to "pull oneself up by the hair" to obtain as rich, full and deep an understanding as possible. And the reasoning as well as the continous changes of the research design, illustrate an openness to and respect for the theme as well as the research subjects. This magnanimity is also expressed in a methodological chapter ("On understanding the general through the particular" - my translation) where a self-critical examination of the research process is undertaken.

The book was widely used as curricula in sociology in all the Scandinavian countries until the mid - eighties. Then new perspectives on the family entered the scene. Once again, previous understandings were deemed fruitless. The traditional 
family didn't exist any longer. There were the "new families" and even the very idea of the family as a major social institution was contested. In addition, all the emerging knowledge from research on sexual violence made other topics seem more urgent to women researchers and sociologists. Harriet Holter was no exception.

\section{Sexualized Violence and Resistance to Knowledge}

Once again Harriet Holter set out to investigate issues she had not covered in previous research projects. Sexuality was such an issue, absent both in "Sex Roles and Social Structure" and in "The Family in Class-Society". Her persistent focus on aspects of power made sexual relations understood as power relations - and vice versa - her obvious approach and field of interest. Her major contribution in this field is a research project on sexual violence involving children. It was initiated in early eighties, and was one of the first empirical studies on this theme in Scandinavia.

Harriet Holter was well over 60 years old when she embarked in a research field she stayed with until her death. At an age when most academics look forward to retirement, to writing their autobiographies or to refining their previous statements, Harriet Holter had the ambition to uncover - both quantitatively and qualitatively this dark and hidden landscape.

Together with two younger researchers, she set out to investigate the prevalence of different kinds of forced sexuality on children. But the quantitative goal was not the only aim of this project. Just as important was the aim to attain a qualitative picture of this "phenomena" and to develop new concepts and understandings.

The results of the research made it clear that forced sexuality was not uncommon to children. It further revealed that so called "incest" is not limited to family members. Adults, not just parents or relatives, oppress and exploit children sexually to a greater extent than we had known previously. The concept of "incest" is accordingly criticized as unsuitable since it limits and marginalizes our understanding. Instead, the concept "sexualized violence" is introduced to enable us to see the sexual relation between an adult and a child in terms of a power relation 
where the adult violates the boundaries of a child (also violating the relationship as such, between an adult and a child). Because sexualized violence is a concept meant to be employed for all kinds of power relations where sexuality is involved in one way or another - as a means to gaining or exerting control, it opens up for further questions regarding what women and children seem to share under patriarchy.

Besides developing new concepts and understandings, such as those related to "sexualized violence", their research also questioned certain (other) myths that until then had been prevalent. For one, boys are also victims of sexual violence. Second, even women can be offenders. Perhaps most importantly though, was their picture of the male offender. He is not, as previously stated, a sexual deviant (pedophile) that is, according to his definitions and those of his surroundings - who lacks resources, belongs to the "lower classes" or lacks voluntary sexual relations. In regard to social characteristics, he is like most men. This picture of the male offender underlines the perspective implicit in the concept of "sexualized violence"; the problem is (part of) men's masculinity - the connection between power and sexuality.

When the book "Forced to Sexuality" (my translation) came out in 1986, it gave rise to an intense debate in the daily papers as well as in the scientific community. The picture was no doubt shocking, and one couldn't or wouldn't believe it to be true. Figures, statistics, definitions, conclusions, concepts and interpretations were questioned. And some of the critique was justified. It is an extremely difficult field to investigate quantitatively especially since there had been few previous projects from which one could learn by the mistakes of others. When the critique, however, was used as a legitimization for not taking the issue seriously, it confirmed Harriet Holter understanding of "resistance to knowledge".

"Resistance to knowledge" was an issue Harriet Holter had raised persistently since the sixties. First in relation to knowledge produced through research on work-life and now in relation to knowledge about sexualized violence. This time though, the resistance was both more profound and widespread. Like her colleagues in the field, she encountered a resistance to know - to take the knowledge to heart - not only from the public, but also and more discouragingly from colleagues in academia. Besides those few who publicly raised their voices, the rest remained 
silent. They didn't read it, comment upon it or integrate the knowledge into "their" sociology. Today, sociologists still tend to understand sexualized violence as "sickness", abnormality and rare in occurence. The reaction of embarrassed silence, whenever this research of hers was made a topic was like a contamination: the taboo transmitted to her from her research subjects. This reaction made her propose resistance to knowledge as a theme in itself for future research in the field.

\section{She and he - gender in research and politics}

Harriet Holter's last project was to edit and contribute to a book on gender and politics (Holter, ed., 1996) which was collectively developed alongside the new discipline - of the same name - to which she had also contributed. Harriet Holter was now in her seventies and severely burdened by the rheumatism and diabetes she had been fighting for more than two decades. She nonetheless here manages to "make a state of the art" in relation to certain of her core issues and perspectives. In the three chapters of the book, which she authered, she returns to the perspectives she started out with - those presented in Sex Roles and Social Structure - and the issues she has returned to over and over again throughout her whole life as a researcher - power, politics, gender and women's research. It is a sort of "up-dated" summary, where the latest intellectual debates have been taken into account when specifying, re-examining or redefining her own contributions. Old statements are revisited and contested or placed in new contexts. But the voice is the same.

In the first chapter, titled "On Gender and Politics" (my translation), the perspectives on politics as gender and gender as politics are discussed. She claims that "politics are in several ways a gender marked business - and vice versa, gender is a political field of experience" (my translation, Holter 1996, p.14). In the chapter her aim is to illustrate in some detail that;

"...gender is, among other things, a social distribution system, in our society both gratifications and burdens are gender differentiated. And the distribution of gratifications and burdens is one of the core areas of politics, particularly in regard to the distribution of power. In this way, gender and politics overlap so that the study of gender becomes a study of politics. But gender distributions often appear as politically neutral, they appear as natural or as voluntarily chosen 
by those who end up with the shortest straw. And vice versa: Political distributions appear as gender neutral." (My translation, Holter 1996 p.14).

Here we recognize perspectives presented in citations from her book "Sex Roles and Social Structure". But the connections to politics and power are stated more directly. All condensed but beautifully expressed, in her special way.

In the second chapter titled "Gender, Politics and Oppression of Women", she discusses the idea of "new women and new men", "conditioned equality" and "differences between women", before revisiting two analyses which have been contested classics in Scandinavian women's research. One is her model for understanding the oppression of women and the other is her claim of male dominance through the integration of women into diminishing institutions ("enter women, exit power", my expression). The first analysis, which became a classic as soon as it was published in an article (Holter 1976), is here totally up-dated with examples and discussions of forms of male dominance other than those discussed 20 years earlier. Regretfully, this rewriting has not been a topic in itself, although it would have been of great interest to learn about her reflections in this matter. That is however the case with the second analysis, which is a part of the previously mentioned "classic" article. Here she confronts the critique of her thesis "enter women - exit power", arguing that even though the examples given by her at that time proved not to support her thesis, other examples from recent research, do provide such proof. It should (still) be investigated, claims Harriet Holter, whether this is a standard pattern for the way democracies give half integration to half unwanted groups, such as women and immigrants.

In the third chapter, finally, she discusses the developments and approaches in women's research. This is also a topic she has written about before, in articles and books throughout the years (for example in Holter 1992). Always though, in a new way, including recent ideas and research, without loosing a historical and contextual perspective. This time reflections on her own development, are more explicit, the concept of sex roles, for example, is discussed anew.

Few have the knowledge and the insights - and the respect of other( $\left.\mathrm{s}^{\prime}\right)$ thoughts that Harriet Holter gives such evidence of in the last chapter of her last book. She ends as strongly as she started, ahead of her time. 


\section{Organizing for knowledge}

The above - mentioned books and projects do not provide a complete list of Harriet Holter's production. They do, however, point to some of her major fields of interest and ways of thinking. The remarkable fact - and rare, I would dare to state - that she, until her very end, was not only intellectually updated, but also ahead of her time regarding issues, approaches and concepts, is not only notable in itself but should also be reflected upon. Personally, I believe this to be a sideeffect of her "organizing for knowledge".

By always supporting, aligning and working with younger generations of researchers and students, she "kept in touch". Her genuine interest in other(s') ways of thinking, and her open mind created a climate where both supervisor and supervised could thrive. In her, the younger women's researchers might very well look for a mother figure, while Harriet herself wanted dialogue partners and a challenging intellectual relationship based on equality. No doubt, the collaborations meant as much to her as to them. This is probably one of the reasons why she put so much effort into exploring different ways of working collectively. The above mentioned projects are not the only examples of such work. She even developed an "umbrella project" called "Women Together" (my translation of "Kvinner i felleskap"), to gather women's researchers to mutual exchange and support. It was an invitation to women researchers to work together on the theme "women together". A book, new projects and networks were some of its more visible results. That the Norwegian Research Council financed such an endeavor in addition to a part-time supervisory position for her, illustrates a public recognition of her ways of "organizing for knowledge". In the other Scandinavian countries, her models for collaboration were envied among the women's researchers who would have loved to belong to her "gang".

The impact of her "organizing for knowledge", for developing new issues, fields and thoughts but also for recruiting new researchers as well as holding on to those already established, can not be emphasized enough. Harriet Holter is the mother of several research programs and projects, and the intellectual mother of women's researchers. Here, I also claim that this way of working affected her own 
intellectual thinking. What she gave, she was given back, and I think she knew this quite well.

\section{Explaining Harriet Holter}

As sociologists we look for patterns and explanations. So have I, when I have here tried to grasp and present the works and thoughts of Harriet Holter. I have stressed her interdisciplinary background, her generation-gendered experiences, her siding with the oppressed and her ways of collaborating intellectually, as some of the reasons for her particular voice and outstanding contribution to sociology and women's research. Other presentations of her work - with or without other patterns and explanations - are of course also possible. My purpose for looking for these patterns and explanations, is that they might inspire us all to reflect upon how knowledge that liberate may best be undertaken. And this, I believe, is to be true to the spirit of Harriet Holter. 


\section{References}

Chodorow, N. 1978. The Reproduction of Mothering Berkeley: University of California Press

Hirdman, Y. 1988. Genussystemet - reflexioner kring kvinnors sociala underordning. (The Gender System - Reflexions on the Subordination of Women", in Swedish), Kvinnovetenskaplig tidskrift, no 3, $49-63$

Holter, H. 1970.Sex Roles and Social Structure. Oslo: Universitetsforlaget.

Holter, H. 1973. Könsroller och samhällsstruktur (Sex roles and Social Structure, translated to Swedish). Stockholm: Prisma.

Holter, H., Ve Henriksen, H., Gjertsen, A \& Hjort, H. 1975. Familien i klassesamfunnet ( "Family in Class-Society”, in Norwegian). Oslo: Pax, in Swedish 1976, Stockholm:Aldus.

Holter, H. 1976. Om kvinneundertrykkelse, mannsundertrykkelse og hersketeknikker (On the Oppression of Women and Men, and Ruling Techniques, in Norwegian). In Støren, T \& Schou Wetlesen, T. (eds.) Kvinnekunnskap, pp 61-83. Oslo: Gyldendal.

Sætre, M., Holter, H \& Jebsen, E. 1986 Tvang til seksualitet (Forced to Sexuality, in Norwegian). Oslo: Cappelen.

Holter, H. (ed.). 1996. Hun og han: kjønn i forskning og politikk (She and He: Gender in Research and Politics, in Norwegian). Oslo: Pax.

Magnusson, E. 1998 Vardagens könsinnebörder under förhandling - om arbete, familj och produktion av kvinnlighet (Negotiating the Everyday understandings of Gender - Work, Family and Production of Femininity, Ph. D. Disseration in Swedish), Doktorsavhandling. Umeå universitet, Sweden

Ve, H. 1992. Sosiologi og forståelser av kjønn (Sociology and Understandings of Gender, in Norwegian). In Taksdal, A. \& Widerberg, K. (eds.) Forståelser av kjønn, pp 149-171. Olso: Ad Notam 